\title{
Er det frækt at være fræk? \\ - En litteraturhistorisk baseret diskussion af obskøne ords brug
}

\section{Introduktion}

Denne artikels formål er at præsentere en diskussion af obskøne ords anvendelsesmuligheder med udgangspunkt i eksempler fra litteraturhistorien og med særligt henblik på den erotiske sfære. Som udgangspunkt benyttes C. S. Lewis’ kommentar til den i det tyvende århundrede så skelsættende debat omkring pornografisk litteratur, der opstod i kølvandet på D. H. Lawrences udgivelse af romanen Lady Chatterley's Lover (1928).

Det bør betones, at det ikke er artiklens ambition at give en nøjere Lawrence-fortolkning, og slet ikke at give en udtømmende redegørelse for den pågældende romans filosofiske og kunstneriske sigte, men kun at sætte fokus på ét bestemt aspekt af værket, nemlig forfatterens meget bevidste brug af obskøne ord, og den filosofiske begrundelse, han angiver for at bruge dem så målrettet $\mathrm{i}$ trods mod tidens konventioner. Denne obskønitets-filosofi - der kan betegnes som et 'afsjoflings-projekt', idet Lawrence har til hensigt at 'vaske det beskidte' ud af de obskøne ord ansporer Lewis til nogle kritiske refleksioner i essayet "Four-letter Words" (1961) omkring obskøne ords ydeevne, først og fremmest med henvisning til de historiske sammenhænge, hvori denne type ord tidligere er blevet brugt Europa rundt på tværs af sprog, religioner og kulturer.

Jeg diskuterer de to positioner ud fra 1) en række eksempler på, i hvilke sammenhænge og med hvilken funktion obskøne ord benyttes i europæisk litteratur (prosa og lyrik) i forskellige historiske perioder og sprogområder, under anvendelse af Lewis' metode fra "Four-letter Words", samt 2) en sproglig analyse af passager fra Lady Chatterley's Lover.

Det bør ligeledes gøres klart, at artiklen heller ikke har til formål at sætte Lewis’ overvejelser omkring obskøne ord i relation til hans tænkning som helhed, eller på anden måde at bidrage specifikt til Lewis-forskningen. Både inddragelsen af Lewis’ og af Lawrences respektive refleksioner må snarere betegnes som anledninger til at få belyst temaet om de obskøne ords anvendelsesmuligheder end som formål i sig selv. 


\section{Obskøne ords historie: Lewis' smutkig}

C. S. Lewis (1898-1963) skrev i 1961 et lille essay med titlen "Four-letter words". Dette er som bekendt den engelske betegnelse for det, der på dansk hedder "frække ord". På engelsk har adskillige af disse nemlig fire bogstaver - man kan selv hurtigt i hovedet lave en lille opremsning!

Lewis har moret sig med at støve lidt omkring i antikke og middelalderlige tekster efter obskøne ord for at efterprøve, hvilke kontekster de forekommer i. Han understreger, at der ikke er tale om nogen systematisk forskningsindsats fra hans side, men kun et lille smutkig ind på et interessant område. Ikke desto mindre finder han, at det indsamlede materiale, begrænset som det er, allerede synes at tegne et mønster.

I Lewis' optik er der nemlig, når man går tilbage i historien, to forskellige typer situationer, hvor man bruger obskøne udtryk. Den ene er den komiske: Når man vil have folk til at le. Lewis bemærker, at opslag i Lidell \& Scott-ordbogen under de følgende græske ord:

Bdeõ (stinker - betyder også prutter, hvad der er det relevante her); bineõ (går i seng med, horer eller voldtager $\left.{ }^{1}\right)$; peos (penis); prõktos (bagdel eller anus); styomai (får erektion); titthion (bryst eller brystvorte, men, tilføjer Lewis, "vistnok i en meget grovere udgave af betydningen", samt kheksõ (har afføring ${ }^{2}$ ) (Lewis 1969: 172)

alle henviser næsten eksklusivt til steder hos Aristofanes eller andre komiske forfattere (Eupolis, Kantharos), hvor ordene bruges i slapstick-scener. Således er der f. eks. kun Aristofanes-referencer til bdeõ, peos og prõktos. Lewis har ret i, at man må tage sådanne ordbogsopslag for, hvad de er, men det er alligevel en tankevækkende iagttagelse.

Fra latinske forfattere fremdrager Lewis fem obskøne ord: cunnus, der har samme betydning som det åbenbart i klassisk tid vulgære vulva (også skrevet volva); samt verpa, der betyder det samme som penis, og verbet glubo (bogstaveligt: 'skræller' eller 'afbarker', dvs. trækker forhuden tilbage i forbindelse med onani eller samleje). Cunnus forekommer oftest hos den ultragrovkornede satiriker Martial, og penis bruges i to betydninger: i sobre tekster med den abstrakte betydning 'begær', men når det betegner den konkrete kropsdel, er det ifølge Lewis kun at finde i satiren (såsom Horats' 12. epode eller en trækkerdrengs tale hos Juvenal IX, 43 (Lewis 1969: 171)). Vulva har i øvrigt hos de latinske forfattere også en videnskabelig brug som anatomisk betegnelse ved siden af den obskøne. De øvrige ord findes især hos Martial, Juvenal og Catul; om glubo siger Lewis malende, at 
"få glemmer det ene sted, hvor de er stødt på det. Glubit magnanimi Remi nepotes udskriges til os i raseri af en mand, der er så ulykkelig, at hans eneste ønske er at såre (LVIII)" (Lewis 1969:171). Catul bruger ordet om sin førhen elskede, nu hadede, Lesbia, som han fornærmer ved at sige, at hun er reduceret til en gadeluder, der går og "skræller [glansen] på den ædle Remus' arvinger" i baggårdene (Lewis 1969:171).

Med hensigten om at såre er vi fremme ved den anden brug af obskøne udtryk, som Lewis har noteret sig. Den er den krænkende. Ud over at skulle vække latter bruges obskøne udtryk til at tilsvine sine fjender med, at vække vrede og ydmygelse. Foruden Catul nævner han i denne sammenhæng atter Martial som udskældende bidragyder (XI, 61), og Juvenal (VI, 129) i et angreb på kejser Claudius' hustru Messalina, berygtet $\mathrm{i}$ samtiden som nymfoman: "adhuc ardens rigidae tentigine volvae", en vending, der af Susanna Braund oversættes med: "stadig brændende, med betændt og stiv klitoris" (still burning with her clitoris inflamed and stiff (Braund 2004: 245)).

Hos Chaucer (ca. 1343-1400) finder Lewis de middelalderlige, obskøne udtryk bele chose, queynte, quoniam, coillons, ers, fart, pisse og swiven. De tre første betegner de kvindelige kønsdele, det fjerde svarer til coilles, ers kan, hvis man skeler lidt, gennemskues som forløberen til den nyere version arse, de to næstsidste ord er også genkendelige for folk med kendskab til nutidigt engelsk, og swiven svarer til screw og har endda en lignende, bogstavelig betydning: at dreje eller hvirvle rundt. For dem alle hævder han (med fyldige referencer til Canterbury Tales), at de kun forekommer i slapsticksituationer og vredesudbrud. (Lewis 1969: 169f).

Fra mit eget studium af middelhøjtysk litteratur kan jeg umiddelbart - hvilket vil sige: Jeg har ikke søgt målrettet efter dem, så det er en relativt ydmyg betragtning - bekræfte noget lignende for ord såsom fud (de kvindelige kønsdele) og gimpel gempel (de mandlige ditto - man kan næsten se på udtrykket, at det skal være sjovt. Det er også betegnelse for en bestemt dans). Jeg er kun stødt på dem i komiske digte og sange (såsom i Neidhart von Reuentals sang Ich erwinde niemer (L 75, Krüger 1993³) om en uheldig voyeur, der i en skov gemt bag et træ får sin rivals gimpel gempel at se forst $\mathrm{i}$ sin egen udkårnes hvide hånd, så filtret ind i hendes kønshår (gran); omend et eksemplar inden for genren Minnerede, "lovprisning af den gode fud" (cgm 270, Leiderer Nr. XII; Krüger 19934) også synes mig at indeholde et alvorligt ment glædesudbrud. Fudens farve, form og hvordan den føles i brug beskrives detaljeret og også kærligt. Men det bliver komisk, når der 
står:

en god fud får æsler til at bræge,

en god fud får fugle til at skrige...

Og tonen i digtet farves naturligvis derefter.

Til gengæld hævder Lewis - og her kommer den pointe, der er hovedsagen for mit emne - at han ikke har kunnet finde et eneste eksempel på, at obskøne udtryk blev brugt til at skabe en erotisk stemning, til at pirre eller ophidse. I tekster, der skal virke seksuelt inciterende på deres publikum, afstås derimod fra disse ord. Lewis skriver, med cunnus som eksempel:

Sådan er de sammenhænge, i hvilket det [cunnus] tages i brug. Bemærk, hvor det ikke gør. I en ægte pornografisk passage, hvormed jeg mener én, der klart er beregnet på at virke som et pirringsmiddel på læseren, har Ovid god lejlighed til at nævne ordets genstand; men han kender sit fag alt for godt til at bruge ordet selv. Han foretrækker to meget opflammende omskrivninger: partibus illis In quibus occulte spicula figit Amor og loca . . quae tangi femina gaudet (Ars Am., II, 707, 719). Apuleius bruger feminal (Met., II, 16, 17) i sin sovekammerscene. Jeg er ikke sikker på dets status ${ }^{5}$, men det skulle overraske mig, om det var så groft som cunnus. (Lewis 1969: 171)

Med andre ord: Når der skal skabes en egentligt intim stemning, en erotisk varm stemning, fordamper brugen af obskøne ord. Ovids to omskrivninger, som Lewis finder ophidsende, lyder i oversættelse: "i de dele, hvor Amor hemmeligt prikker med sine små pilespidser" og "de steder, hvor kvinden glæder sig ved at blive berørt". For en elskovsscene hos Chaucer, der efter Lewis' vurdering besidder et reelt pirringspotentiale, konkluderes noget tilsvarende (Troilus and Criseyde III, 1142-1421). Her ville, hævder Lewis, "hvert ord (omend visselig ikke passagen som helhed) kunne have været læst højt i en victoriansk pigeskole” (Lewis 1969: 170). Men hvad skal man så udlede af det?

\section{Adams, Henderson og andre om historisk og nutidig obskøn sprogbrug}

I The Latin Sexual Vocabulary af J. N. Adams understøttes Lewis' iagttagelse i det latinske tilfælde for så vidt i Adams' konklusion (Adams 1990: 214ff.), hvor denne indleder med at give et overblik over sociolingvistisk 
og kontekstuel variation i brugen af obskøne udtryk i det kejserlige Rom, og skriver:

Det seksuelle vokabular kan ikke uden videre fordeles på forskellige sociale dialekter på latin. Basale obskøniteter blev brugt af alle klasser. Det er sandt, at graffiti kradset ned af halv-analfabeter er spækket med obskøniteter, men medlemmer af de dannede klasser gjorde også brug af den slags ord $i$ passende sammenhange. ${ }^{6}$ (Adams 1990:214)

$\mathrm{Nu}$ er det interessante naturligvis, hvad passende sammenhænge (appropriate contexts) så er ifølge Adams. Han fortsætter med følgende specifikation:

Man finder mentula, uerpa, cunnus, futuo, pedico, irrumo og fello brugt på stort set samme måde af Catul og Martial i epigrammer som af vægskribenter i Pompeii. Augustus rettede seksuelle fornærmelser mod Antonius med de samme vendinger, som blev brugt af Pompeiis indbyggere. (Adams 1990:214)

Og der følger flere tilsvarende eksempler. Vi kan notere os, at det atter for det første er satirikerne, der nævnes - epigrammer, der skal more og støde - og for det andet et eksempel på obskøne ord brugt til at fornærme en politisk eller personlig modstander. Endvidere supplerer Adams med information om, hvor de obskøne ord ikke anvendes:

Naturligvis var der omstændigheder, hvorunder obskøniteter ikke blev tolereret af de dannede, som for eksempel i oratoriet eller i diverse litterære genrer. Men man er nødt til at have en skelnen mellem 'vulgariteter' (underklassebrug, der ofte fremviser morfologiske og fonetiske afvigelser fra den dannede norm) og obskøniteter. Vulgaritet i denne snævre forstand var stort set udelukket fra [eller: fremmed for (alien)] de litterære genrer og utvivlsomt også fra dannet tale. (Adams 1990: 214. Min kursivering)

Underklasseslang er desværre kun lidet bevaret. Men væsentligere for denne artikels tema er også Adams' implikation af, at folk, der har ordet $i$ deres magt og er trænede $i$ at finde det mest præcise udtryk for deres hensigt, reserverer de obskøne ord til netop de to kontekster, Lewis opregner i sit essay. Når man taler obskønt, så er det enten, fordi man vil være morsom, eller fordi man vil nedgøre nogen.

På side 7 modsiger Adams dog Lewis, idet han medregner pirring som et formål med de obskøne ord, og også kan henvise til direkte tilkendegivelser af en sådan hensigt hos Martial; i 11.16.5ff omtaler denne således sine vers som stimulerende for både mænd og kvinder; og sammenligner $\mathrm{i}$ 1.35.4f den glæde, brugen af ordet mentula (et slangord for penis) vækker, 
med den glæde, som genstanden for ordet giver en kvinde (ibid. 8). Det sidste eksempel er stærkest: Her sigtes der uimodsigeligt til seksuel pirring. Udgiverne af et Martial-udvalg, P. og L. Watson, mener imidlertid, at Martial ikke efterlever sin egen programerklæring; de skriver i indledningen:

Det er værd at bemærke, at obskønt sprog næsten aldrig bruges af pornografiske grunde, dvs. med den udtalte hensigt at bevirke en seksuel pirring $\mathrm{i}$ læseren, selvom Martial påstår, det er en af dets funktioner [...]. (Martial 2003: 22. Min kursivering)

I stedet opremser de de samme former for brug af obskøn tale, som vi allerede har hørt om: hån og latter.

Endvidere omtaler Adams en brug af obskøne ord, som Lewis ikke har med, skønt den burde interessere ham som lægmandsteolog: nemlig en religiøs brug: apotropaisk obskønitet. I førkristen romersk sammenhæng brugte man at råbe vulgære ord ud over gader og stræeder ved triumftog, til visse helligfester og til bryllupper for at bortjage onde ånder (Adams 1990: 4ff.). Denne tanke synes at ligne den danske folketro om, at en kvinde kunne skræmme overnaturlige væsener såsom nisser, hvis hun slog skørterne op ${ }^{7}$ og viste dem sin nøgne bagdel eller sit køn. En direkte og uventet konfrontation med ordet for eller synet af et menneskeligt kønsorgan tænktes åbenbart at virke skræmmende. Hvilket også giver psykologisk mening på flere planer: Menneskets kønnethed er jo for det første implicit en mindelse om dets dødelighed. Livet føres videre gennem kønsorganerne, men den næste generations komme bebuder også den nuværendes ældning og dod (Beauvoir 1977: 202ff.). For det andet har ikke så få mennesker personligt smertelige erfaringer på dette følsomme område, og dette var næppe mindre almindeligt i tider med ringe eller ingen retssikkerhed og lavere aldersgrænser for ægteskaber. Også den høje dødelighed ved barsel kunne bidrage til at omgive kønnet med en aura af elendighed og angst.

Digt nr. 28 i Priapeia, en samling digte fra omkring år 0 af ukendte forfattere omhandlende den komisk-falliske gud Priapos, altid afbildet med en erektion i overnaturlig størrelse, ser ud til at beskrive denne religiøse og (ære)frygtprægede brug. Det lyder:

Gid jeg må dø, Priapos, hvis ikke jeg skammer mig ved at bruge sjofle og upassende ord.

Men når du som en gud, der fralægger dig skam, åbent viser mig dine kugler, 
så påhviler det mig at råbe [egentlig: kalde (på)] "pik" og "kusse". (Anon. 1664: Carmen XXVIII.)

Det er et interessant digt, fordi det udtrykker en konfliktfyldt stemning af skam over for pligt (pålagt ritual). Skam over for obskønt sprog samt advarsler imod det findes i øvrigt hyppigt i den romerske verden, for eksempel hos Cicero i De officiis (Om pligter), hvor det hedder i en kritik af kynikerne:

Vi må bestemt ikke lytte til kynikerne [...], når de kritiserer og driller os, fordi vi mener, at skønt visse ting ikke i sig selv er æreløse, så er ordene for dem forbundet med skam, mens vi [på den anden side] kalder ting ved deres eget navn, som [i sig selv] er æreløse. (De officiis 1.128: Griffin 1996: 191)

Kynikernes kritik skulle ifølge Cicero gå på, at det ud fra deres synspunkt er mere skamløst at tale åbent om onde gerninger end at ville kalde f. eks. kønsorganer, som jo i sig selv er uskyldige, ved navn. Det er der da også en pointe i. Men Cicero afviser denne kritik og anfører i stedet, at det hører til decorum (anstændig optræden) at undgå at tale alt for åbent om bestemte kropsdele; naturen selv, påstår han, viser ved at skjule bestemte kropsdele, at deres brug og beskrivelser af dem ikke bør være offentlig (De officiis 1.128; Griffin 1996: 192). Denne tanke findes også i hellensk kultur, tidligst hos Xenofon ${ }^{8}$ (Mem. 1.4.6; Henderson 1991: 6.).

I The Maculate Muse giver Jeffrey Henderson med henblik på den attiske komedie en opsummering af obskønitet og de obskøne ords brug, der meget ligner Lewis'. Han skriver:

[...] obskønitet bruges som oftest til at fornærme nogen; til at understrege, hvad man siger, på stærkest mulig vis; til at forbande med; til at levere kraft til komedier, vittigheder, latterliggørelse og satire. (Henderson 1991: 7)

Mens obskønitet ifølge Henderson ofte bruges for at nedgøre det objekt, den refererer til, mener han dog også, at den kan bruges til at vække en kortvarig form for seksuelt relateret fornøjelse. Men han opretholder et væsentligt skel mellem pornografi og obskønitet ${ }^{9}$ ved at pointere, at pornografien sigter mod en tilfredsstillelse af brugerens detaljerede seksuelle, forbudte fantasier, mens obskøniteten blot skal skaffe ham morskaben ved "en kort og uhæmmet udladning af seksuelle følelser" (Henderson 1991: 8). Han mener hermed forskellen mellem en seksuel udløsning og befrielsen ved en latter (om skellet mellem pornografi og obskønitet kan 
man sige meget mere, men af pladshensyn må jeg nøjes med at give dette glimt af distinktionen). Denne er ganske rigtigt en helt anden stemning end den, som pornografien sigter efter. Som det hedder hos E. Mertner og H. Mainusch i Pornotopia: "Den obskøne vittighed findes, men ikke den pornografiske“ (Merkur og Henderson 1970:40).

For at beskrive en cirkel tilbage til Lewis igen, så udbygger han sín version af dette skel ved at vende sig til et par tekster fra 1600-tallet, der netop kritiserer obskøne ord for at have en anti-ophidsende effekt. Her er pointen stærkere end hos Henderson, der mente, at obskøn sprogbrug havde et beskedent, seksualiserende potentiale. Her tolkes den som decideret afseksualiserende. Jeg citerer den ene af teksterne (den anden er af Montaigne), et vers af John Sheffield (1648-1721), der kritiserer en anden digter for at have brugt obskøne ord og derved at have dræbt lysten hos sine læsere. Sheffield lægger ikke fingrene imellem i sin kritik:

[Det er] ikke sådan, at varme tanker om den opløftende glæde kan forarge den mest bly eller overmætte den pæneste; men obskøne ord, for grove til at vække attrå, som store dynger brænde kvæler bare ilden.

Den digters navn fortjener ikke ros, der sløved' appetitten, som han ville skærpe.

(Lewis 1969: 173)

Her påstår Sheffield, at han ikke kritiserer brugen af obskøne ord ud fra en moralsk forargelse, men fordi han synes de dræber den gode (erotiske) stemning. Lewis slutter sit essay med at kalde denne effekt for et resultat af, at obskøne ord er ladet med "lige det modsatte onde af, hvad de snerpede mistænker dem for - med en gnostisk eller Swiftsk foragt for kroppen" (Lewis 1969:174). Hermed mener han, at de udtrykker en stemning af aggression overfor, og afstandtagen til, det, de betegner.

\section{Lawrences afsjoflingsprojekt}

Men nu til den tænker og den tanke, der var den umiddelbare motivation for Lewis' essay. Det var den flodbølge af debat, blandt andet omkring censur, men også om det erotiskes rolle og natur, som blev sat i gang af D. H. Lawrences (1885-1930) sidste og i dag berømteste roman, Lady Chatterley's Lover, og fortsatte med at flyde i årtier. Lawrences projekt med bogen var grundlæggende at legitimere sexlyst i en sexkritisk samtid; i sex - ellere 
rettere, $\mathrm{i}$ elskov, for han mente ikke, at den fysiske aktivitet var tilstrækkelig, den skulle også være kærlig og inderlig ${ }^{10}$, før den blev sund (Lawrence 1993: 206 ff.) - så han menneskets centrale kilde til psykisk sundhed og livskraft. Han bød også i romanen på en metode til at nå frem til dette mål, til legitimeringen af sex i den almindelige bevidsthed. Metoden hertil var at tale om sex ${ }^{11}$. Åbent og direkte, og det indebar efter Lawrences mening også at integrere de obskøne ord i dagligsproget. Herom tænkte han som antikkens kynikere. Hans projekt var at afsjofle de obskone ord - forskønne det vulgære ved dem gennem en demonstrativt dels normaliserende og dels erotisk brug af dem. Så i Lady Chatterley forsøgte han sig med at bruge fuck, arse, cunt og også shit - som om ikke blot de betegnede ting og handlinger, men også ordene selv, var neutrale. I sit essay "A Propos of 'Lady Chatterley's Lover' " forklarer han sin baggrund for det. Der er intet galt med kroppen og dens funktioner - men med sindet: "Sindet (the mind) har en gammel, krybende frygt for kroppen og kroppens muligheder (potencies). Det er sindet, vi er nødt til at frigøre, at civilisere på disse punkter.” (Lawrence 1993:309)

Som eksempel på et kropsangst sind nævner Lawrence Jonathan Swift $(1667-1745)^{12}$, som skrev et digt om kvinden Celia og hendes tilbeder Strephon med det rædselsslagne (maddened) udbrud: "Men - Celia, Celia, Celia skider!” Her ser vi, kommenterer Lawrence,

hvad der kan ske med en stor begavelse (mind), når den går under i panik. En så skarpsindig mand som Swift kunne ikke se, hvor latterlig han gjorde sig selv. Selvfølgelig skider Celia! Hvem gør ikke? Og hvor meget værre, hvis hun ikke gjorde! Det er håbløst. Og tænk så på stakkels Celia, bragt til at føle sig beskæmmet over sin naturlige funktionsmåde, af sin "elsker". Det er uhyrligt. Og det kommer af at have tabuord, og af ikke at holde sindet tilstrækkelig udviklet i fysisk og seksuel bevidsthed. (Lawrence 1993:309)

Lawrences indignation brænder stærkt igennem hans ord her. Der er ingen tvivl om, at det er en hjertevarm mand, der taler, en mand, der under andre mennesker glæde frem for skam ved deres krop. Af samme grund stritter han også aktivt imod associationen mellem kønslighed og komik. Han lader sin romanheltinde, Lady Chatterley, bemærke det latterlige ved den menneskelige måde at parre sig på - hun fokuserer her særligt på mandens bagdel, der vipper op og ned - og dette indtryk virker også umiddelbart distancerende på hende (Lawrence 1993:126). Men senere favner hun latterligheden og elsker den, og i det samme får hun erotikken tilbage også 
i og med det latterlige. Eller rettere, hendes accept gør, at det latterlige transformeres til pur skønhed (Lawrence 1993:174ff).

Lawrence er her vist inde på noget psykisk konstruktivt, den teknik, han skitserer, kan jo nærmest betegnes som en øvelse i caritas: barmhjertighed med sit fumlende medmenneske. Rummelighed kalder man det også med et lidt mere dagligdags (men også lidt mindre rammende) udtryk. Man mindes om Oscar Wildes visdomsord: "Livet kan ikke forstås uden et væld af barmhjertighed, kan ikke leves uden et væld af barmhjertighed" (Wilde 1986: 448).

Lawrence accepterer ud fra dette perspektiv heller ikke, at en bestemt slags ord med direkte, seksuel betydning i sig selv kan være latterlige. Han mener, det er den indstilling, som får os til at le (hånligt, bange eller overfladisk), der er problemet. (Lawrence 1993: 171ff). Og i det øjeblik, et menneske får modet til at gå ind i oplevelsen af lyst og glæde, får selve ordene deres skønhed og værdighed igen - det er hans tanke.

\section{Virker det? Lawrence vs. Lewis}

Det opsamlende spørgsmål i forhold til denne artikels tema må nu være: Virker denne del af Lawrences strategi? Bidrager de obskøne ord reelt til at åbne for lysten og bane vejen for en mere inderlig sanselighed?

Det er et spændende spørgsmål, som man nok skal være varsom med at forsøge at levere et endegyldigt svar på. Men omend Lawrences tanke $\mathrm{om}$ at nå hinsides latterligheden og til en mere favnende bevidsthed er sympatisk, forekommer kritikken mig at stå stærkest. Dette af to grunde:

Den ene drejer sig om årsagerne til, at obskøne ord er obskøne. Hvis de kun hentede deres chokeffekt fra snerpethed, fra en lokal, kulturel afstandtagen til sex, så ville Lawrences forslag være enklere at realisere. Men som vi netop har set af Lewis' og andres redegørelser for traditionel brug af obskøne ord på tværs af kultur og religion (ganske vist kun i europæisk sammenhæng, hvilket svækker pointen noget - men lad os for indeværende blot notere, at den spænder over både antik polyteisme, kristendom og nutidig, sekulariseret kultur), så vækker ordene også krænkede reaktioner i kraft af, at de gennem årtusinder har været brugt til - krænkelse og latterliggørelse. Det vil sige, at de ikke kun støder i kraft af deres seksuelle reference, men også i kraft af en praktisk funktion, som ikke er seksuel. Hvor man hører obskøn sprogbrug, er der signaleret enten fjendtlighed eller fjolleri. Det er formentlig disse iboende associationer, der af Sheffield 
opleves som erotikdræbende. Aggression er ikke befordrende for intim hengivelse, og et bøvet grin heller ikke.

Men dette betyder, at Lawrence ikke kun er oppe imod en fortielse af seksuelle emner - altså en fraværende eller reduceret brug - når han vil æstetisere obskøne ord eller erotisere dem, men også mod en aktiv, enten negativt eller målrettet uæstetisk (lattervækkende) ladet brug. Det er en markant større udfordring.

Også i dag bruges obskøne ord fortsat i dagligdagen som skældsord. Cunt, som Lawrence forsøger at bruge i kærlige situationer, er den dag $\mathrm{i}$ dag, brugt mod en person, en voldsom krænkelse. (Betegnende nok lader Lawrence Lady Chatterleys elsker, Mellors, da denne lærer hende betydningen af ordet cunt, udelade af definitionen, at ordet også kan bruges som skældsord. (Lawrence 1993:178).

I 1987 affejer Andrea Dworkin ud fra et feministisk perspektiv ${ }^{13}$ i sin bog Intercourse Lawrences forslag af netop denne grund. Hun beskriver loyalt, men med indlagt distance, hans projekt således:

Den falliske virkelighed, han sigtede mod, var ekstatisk, ikke beskidt, et kneppesakramente, menneskelig tilbedelse af en ren maskulinitet og en ren femininitet legemliggjort i henholdsvis penis og kusse (et andet af de ord, Lawrence yndede). (Dworkin 2007: 217)

Den indskudte parentes er tydeligvis et udtryk for Dworkins behov for at tage personligt afstand fra selve brugen af ordet 'kusse' (cunt), og hun angiver kort efter sin motivation herfor: at det gængst bruges som skældsord til ydmygelse af kvinder. Hun skriver:

Beskidte ord vedbliver at være beskidte, fordi de udtrykker en foragt for kvinder, eller for kvinder og sex (ofte synonymer), der er ægte, indlejret i fjendtlige praksisser som devaluerer og sårer (...) (Dworkin 2007:217)

Bemærk udpegningen af en tilknyttet praksis hinsides det verbale plan som en forhindring for ændring af ordenes betydning. Overordnet konstaterer Dworkin bagudskuende, at eksperimentet har været forsøgt og er mislykkedes: "På trods af blomsterbørns-generationens indvilgelse i at revidere betydningen ændrede betydningen af fuck sig ikke." (Ibid.) Noget tilsvarende gælder for danske slangudtryk for kønsorganer. Så længe obskøne ord stadig sideløbende bruges som redskaber til krænkelse, er det næppe gørligt at realisere Lawrences ambition. 
Det fører os til den anden grund, som omhandler det historiskes rolle for ords betydningsindhold. I endnu et essay knyttet til temaet obskøn sprogbrug, "Prudery and philology", argumenterer Lewis for, at stemningen af fjendtlighed og grovhed omkring obskøne ord er yderst vanskelig at opløse, fordi den er akkumuleret gennem ordenes tusindårige historie som krænkelses- og latterredskaber (Lewis 2000: 516ff). Et ords historie er en væsentlig del af dets betydningsindhold, og kan ikke uden videre bortopereres - en sådan ombrydning kræver i virkeligheden, at man "sprætter hele bevidsthedens sammenvævning op". (Lewis 2000:517)

Noget sådant er måske nok muligt, siger Lewis, men indebærer et større besvær, end sagen er værd. Han advarer tillige mod faren for at skylle barnet ud med badevandet. For skønt man ikke behøver at forfalde til den dogmatiske forestilling, at erotik i bund og grund er afhængig af tabuer og forbud for overhovedet at være erotik, så er der på den anden side noget om, at en vis grad af ærefrygt $i$ omgangen med emnet er nødvendig for at bevare spændingen. For megen insisteren på det vulgære kan afpirre og affortrylle.

\section{Lawrence vs. Lawrence}

Man kan interessant nok også tydeligt se en følsomhed for dette i Lawrences roman. Trods sin hensigtserklæring bruger han (ligesom Martial) ikeke obskøne ord i bogens målrettet erotiske øjeblikke. I disse er sproget som følger:

Og blidt, med det underfulde dåneagtige kærtegn af hans hånd i ren blød attrå, blidt strøg han den silkebløde kurve af hendes lænder, ned, ned mellem hendes bløde, varme baller, idet han kom nærmere og nærmere til selve hendes følekerne. [...] Hun følte hans penis rejse sig imod hende med stille, forbavsende kraft og bekræftelse, og hun gav sig hen til ham. (Lawrence 1993: 173)

Med andre ord, her er der lander, baller, en metafor i form af en folekerne (the quick of her) for de kvindelige kønsdele, samt en meget ærbar, latinsk penis. Fuck og cunt er ikke med i beskrivelsen af parrets elskov, når den skal formidles som pirrende. Disse ord tager Mellors derimod i brug, når Lawrence skal til at filosofere! Lewis kommenterer noget lignende omkring Jean de Meungs brug af coilles i den allegoriske Rosenroman. Her bruges ordet af den legemliggjorte Fornuft (!), der tilmed bebrejdes for sin sprogbrug af Elskeren (romanen handler om en elsker, der søger en mystisk 
rose, vel at forstå som den elskovsekstase (eller 'sande kærlighed', kunne man også sige), som Lawrence også prædiker som det ene fornødne). Fornuften forsvarer sig med, at det, som ordet betegner, er skabt af Gud med egne hænder, og derfor vil hun ikke nedlade sig til at tale upræcist om det. Her genfinder vi atter det synspunkt, Cicero tilskrev kynikerne. Tal dog frit fra leveren, det er jo naturlige ting! En sund pointe, kan man ikke andet end at synes. Ja, men i næste åndedrag tilføjer Lewis: ’Når Jean de Meung ophører med at fremsætte doktriner, og igen bliver en erotisk digter, så kommer vi ikke til at høre mere til coilles" (Lewis 1969: 173). Det er nok rigtigt. Og det gælder også for Lawrence. Det er i en scene, hvor læseren tydeligt skal belæres om kønsorganernes, og deres ords, naturlighed, at Mellors siger - interessant nok ikke engang direkte til Connie, men til sit eget rejste lem:

Ih, hvor er du fræk! Kusse, det er det, du er ude efter. Sig til lady Jane [: et andet, noget mere eufemistisk, slangudtryk for kvindelige kønsorganer], at du vil have kusse. John Thomas [: tilsvarende slang for de mandlige kønsorganer], og lady Janes kusse! (Lawrence 1993: 210)

Værd at bemærke er Connies svar. Det lyder:

Åh, du må ikke drille ham!" sagde Connie og kravlede på knæ henimod ham og lagde sine arme om hans hvide, slanke lænder, og trak ham ind til sig, så at hendes hængende, svingende bryster berørte spidsen af den dirrende, stive fallos, og fangede dråben af væde. [...] Du må aldrig fornærme ham.(ibid.)

Dette udbrud er interessant, fordi det lyder, som om Connie er mere enig med C. S. Lewis end med Lawrence angående brugen af obskøne ord. Hun synes åbenbart, det er at nedgøre John Thomas at tale sådan til ham om hans fine lady Jane. Og Lawrence selv? Ja, i samme øjeblik, han skifter fra at lade Connie og Mellors tale om sex og går over til at beskrive, hvad de gor med hinanden, og hvordan deres kroppe forholder sig, så er det intet bodegaord, vi får præsenteret, men en "fallos". Lawrences eget, erotiske instinkt modsiger hans filosofiske, udtænkte konklusion ${ }^{14}$. 


\section{Noter}

1 Den sidste betydning har Lewis ikke, den har jeg fra Bergs græskordbog.

2 Lewis bruger for sit eget stillejes skyld sådanne neutrale oversættelser frem for de obskøne, engelske ækvivalenter, og derfor har jeg valgt at gøre det samme, når jeg resumerer ham; men det er at formode, at der burde stå 'skider' her, og tilsvarende for de andre ord.

3 Online på: http://www.rcs-krueger.de/Reuental.htm, lagt ud af forfatteren selv efter 1993-udgaven af den trykte bog. Men uden sidetal.

4 Online på: http://www.rcs-krueger.de/FutLob.htm .

5 Adams 1990: 215 har feminal med på en liste af ord med videnskabelig status snarere end obskøn.

6 Hvor intet andet er anført, er alle oversættelser af citater mine egne.

7 F. eks. brugt i Vilhelm Bergsøes folkesagns-pastiche Nissen (Bergsøe 1889: 91).

8 Det er en myte, at forbindelsen mellem skam og seksualitet er specifikt jødiskkristen.

9 Som også optog D. H. Lawrence, der skrev et essay herom i 1929, Pornography and obscenity. Han definerede dog skellet anderledes.

10 Af denne grund tog Lawrence skarpt afstand fra idealet om 'fri sex' i betydningen afslappet promiskuøsitet ("at dyrke sex, som man drikker en cocktail" (Lawrence 1993: 310)). Han mente, at denne livsstil gjorde folk følelsesmæssigt overfladiske og usanselige, og flyttede deres fokus, inklusive ophidselsen, fra kroppen, hvor den hører hjemme, og til et rent mentalt plan, med emotionelle skader til følge. (ibid. 310-14.)

11 Efter Foucaults analyse af italesættelsen af sex, og selve frigørelsesretorikken, som magtdiskurser i sig selv, kan dette synes en naiv position. Foucault udpeger da også direkte Lawrences essentialistiske opfattelse af sex som en af de ting, han er oppe imod (Foucault 1994: 163-166), men man bør alligevel ikke helt ureflekteret acceptere en direkte modstilling af Foucaults og Lawrences perspektiver, se f. eks. Kellogg 1999. Lawrence var heller ikke blind for, at talen om sex kan anvendes til disciplinering af lysten, jvf. hans analyse af sin tids "mentalisering" af sex (Lawrence 1929: 26).

12 Se Coetzee 1996: 54-56 for en interessant tolkning af, hvorfor netop Swifts digte gør så dybt et indtryk på Lawrence, at han bliver ved med at vende tilbage til ham som skrækeksempel på et forkvaklet sind.

13 Feministiske tænkere har oftest fundet Lawrence ideologisk ufordøjelig (Beauvoir, Millet o.m.a.), en "arketypisk mandschauvinist" (Blanchard 1975: 431). Lydia Blanchard, en af de få, der prøvede at imødegå bølgen af feministisk Lawrencekritik i 70'erne, skrev vemodigt: "Selv de kvinder, der beundrer den måde, Lawrence bruger ord på [en vending, der antyder en positiv interesse for afsjoflingsprojektet], skynder sig at tilføje, at de ikke har andet end foragt til overs 
for den måde, han bruger kvinder på.” (ibid.) Megen Lawrenceforskning har forsøgt at positionere ham i forhold til feministiske diskurser omkring køn og magt, men dette er problematisk, da han skærer på tværs af flere forudsætninger i disse diskurser. Det er da også lykkedes ham på én gang at blive fordømt af både radikale forkæmpere for, og konservative modstandere af, seksuel frigørelse og kvindefrigørelse - hvilket vel kan betragtes som en slags udmærkelse?

14 David Gordon konstaterer tilsvarende efter at have leget med tanken om en mulig dialektik i Lady Chatterley's Lover mellem beskrivelser af erotiske møder som tavshedsskabende og brugen af obskøne ord som seksuelt befriende (1981: 371): "romanen (...) er fuld af de samme selvmodsigende vidnesbyrd, der bevidner Lawrences dybe ambivalens overfor sproglig bevidsthed."

\section{Litteratur}

Adams, J. N. (1990 [1982]): The Latin Sexual Vocabulary, Baltimore: Johns Hopkins Paperbacks Edition.

Anon., red. K. Schoppe et al. (1664): Priapeia: sive diversorum poetarum in Priapum lusus, Ingolstadt: Patavii, apud Gerhardum Nicolaum V.

de Beauvoir, Simone (1977 [1949]): Det Andet Kon, Forste Bind: Kendsgerninger og Myter, København: Tiderne Skifter.

Bergsøe, Vilhelm (1889): Nissen. Danske Folkesagns-Eventyr, København: Ernst Bojesens Kunstforlag.

Blanchard, Lydia (1975): "Love and Power: A Reconsideration of Sexual Politics in D. H. Lawrence", i Modern Fiction Studies, vol.21, nr.3.

Braund, Susanna Morton (2004): Juvenal and Persius, Harvard: Loeb Classical Library.

Coetzee, J. M. (1996): "Lady Chatterley's Lover: The Taint of the Pornographic" i Giving Offense: Essays on Censorship, London: The University of Chicago Press.

Dworkin, Andrea (2007 [1987]): Intercourse, New York: Basic Books.

Foucault, Michel (1994 [1976]): Viljen til Viden. Seksualitetens Historie 1, Frederiksberg: Det lille forlag.

Gordon, David J. (1981): "Sex and language in D. H. Lawrence", Twentieth Century Literature, vol. 27 nr.4: 362-375.

Griffin, Miriam (1996): "Cynicism and the Romans: Attraction and Repulsion" i The Cynics: The Cynic Movement in Antiquity and its Legacy, red. R. BrachtBranham og Marie-Odile Goulet-Cazé, Berkeley: University of California Press, Ltd. 
Henderson, Jeffrey (1991 [1973]): The Maculate Muse: Obscene Language in the Attic Comedy, New York: Oxford University Press.

Kellogg, David (1999): "Reading Foucault Reading Lawrence: Body, Voice, and Sexuality in Lady Chatterley's Lover", D. H. Lawrence Review vol.28, nr.3:s.31

Lawrence, D. H. (1993): Lady Chatterley's Lover. A Propos of 'Lady Chatterley's Lover", red. Squires, Michael, The Cambridge Edition of the Letters and Works of D. H. Lawrence, Cambridge: Cambridge University Press.

Lawrence, D. H (1929): Pornography and Obscenity, London: Faber \& Faber Ltd.

Lewis, C. S. (1969): "Four-letter Words" i Selected Literary Essays, Cambridge: Cambridge University Press.

Lewis, C. S. (2000): "Prudery and Philology" i Essay Collection and Other Short Pieces, red. Lesley Walmsley, London: HarperCollins Publishers.

Martial (2003): Select Epigrams, red. L. og P. Watson, Cambridge Latin and Greek Classics, Cambridge: Cambridge University Press.

Mertner, Edgar \& Mainusch, Herbert (1970): Pornotopia: Das Obszöne und die Pornographie in der literarischen Landschaft, Frankfurt am Main: Athenäum Verlag.

Wilde, Oscar (1986): “An Ideal Husband” i The Complete Illustrated Works of Oscar Wilde, London, Octopus Publishing Group Ltd. 

